\title{
142. Compositional Variation of Olivines in Rocks of the Tari-Misaka Ultramafic Complex and its Interpretation
}

\author{
By Shoji ARAI \\ Geological Institute, Faculty of Science, University of Tokyo \\ (Comm. by Seitarô Tsubor, M. J. A., Oct. 12, 1973)
}

\section{Introduction}

In the course of his petrological study of the Tari-Misaka ultramafic complex, the largest of several Alpine-type ultramafic complexes in the central part of Chugoku district, western Japan (Fig. 1), the writer has come to notice an interesting fact on compositional variation of olivines which constitute the rocks. In this paper the fact is presented with its genetical interpretation.

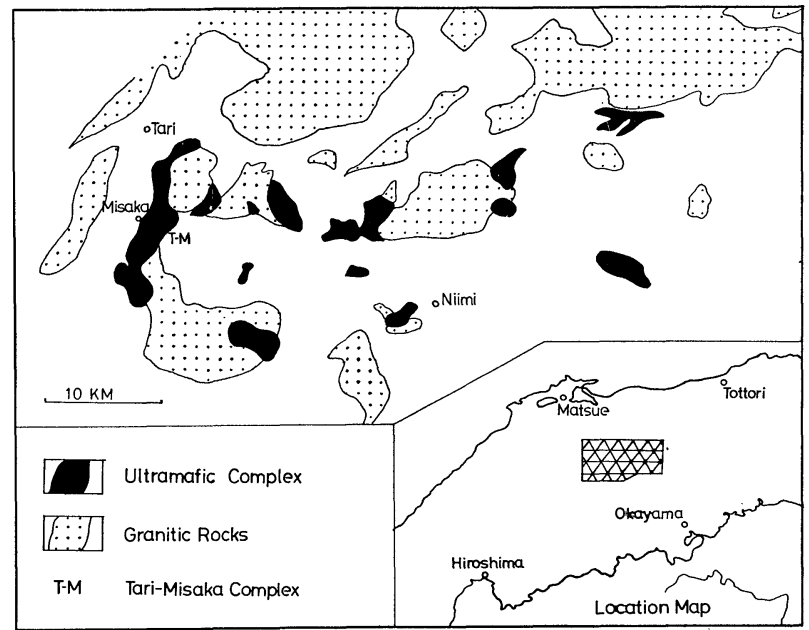

Fig. 1. Distribution of ultramafic complexes and granitic rocks in the central part of Chugoku district, western Japan.

\section{Geological and Petrological Sketch}

The Tari-Misaka ultramafic complex is emplaced into a Paleozoic formation and is intruded by younger granitic masses (Fig. 2). The Paleozoic formation is mainly composed of pelitic sediments, in part thermally metamorphosed into hornfels.

The Tari-Misaka ultramafic rocks may be classified into the following four types according to their mineral assemblages. Besides these occur subordinately hornblende-bearing gabbroic rocks in dikes 
or lenticular bodies through the ultramafics.

Type I': $\mathrm{Ol}+\mathrm{Sp} \quad$ (Dunite)

Type II : $\mathrm{Ol}+\mathrm{Opx}+\mathrm{Sp}$ (Harzburgite, partly Opx-bearing Dunite)

Type III : $\mathrm{Ol}+\mathrm{Opx}+\mathrm{Cpx}+\mathrm{Sp}$ (Cpx-bearing Harzburgite)

Type IV: $\mathrm{Sp}(+\mathrm{Ol})$ (Chromitite)

Ol: olivine, Opx: orthopyroxene, Cpx: clinopyroxene, Sp: chromian spinel

The rocks of Types I, II, and III are dominant and are arranged in semi-concentric zones (Fig. 2) ; while the rocks of Types IV are negligible in amount, occurring as pods in rocks of Types I and II. All of these ultramafic rocks are more or less serpentinized. The serpentinization is more profound in Type III than in Types I and II.

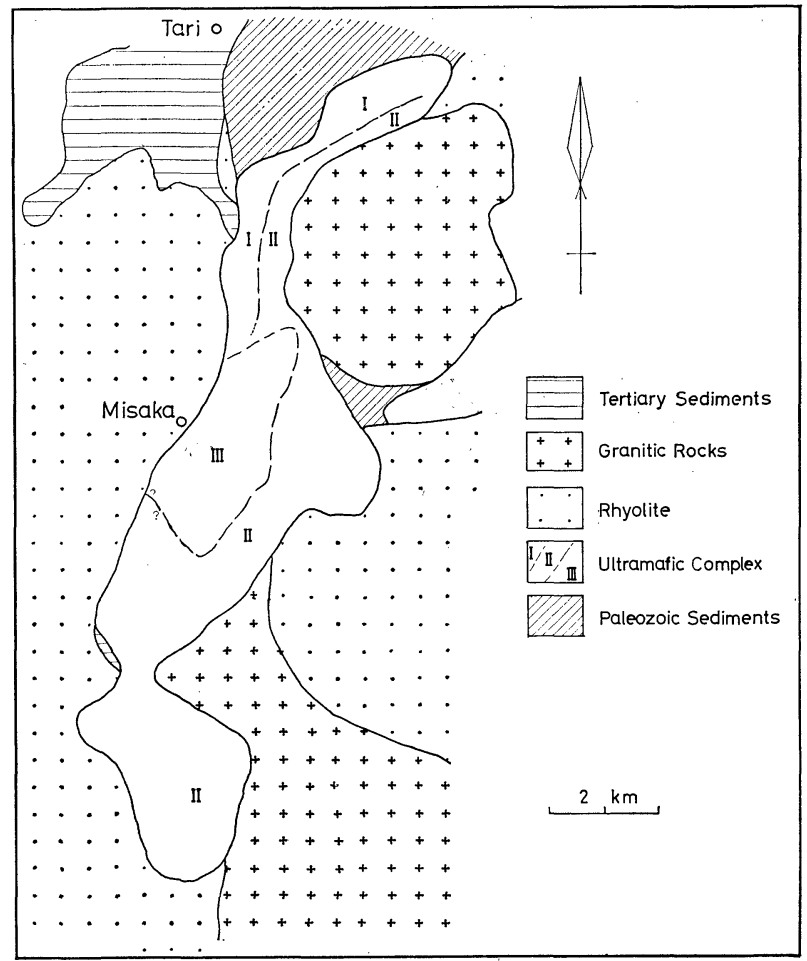

Fig. 2. Geological sketch-map of the Tari-Misaka area. I, II, and III represent respectively Types I, II, and III of TariMisaka ultramafic rocks. (See text.)

Compositions of Olivines and Related Mineralogy

Electron microprobe analyses of olivines and other minerals in the Tari-Misaka ultramafic rocks gave the following results.

In rocks of Type I, the frequency histogram of Fo value (100 

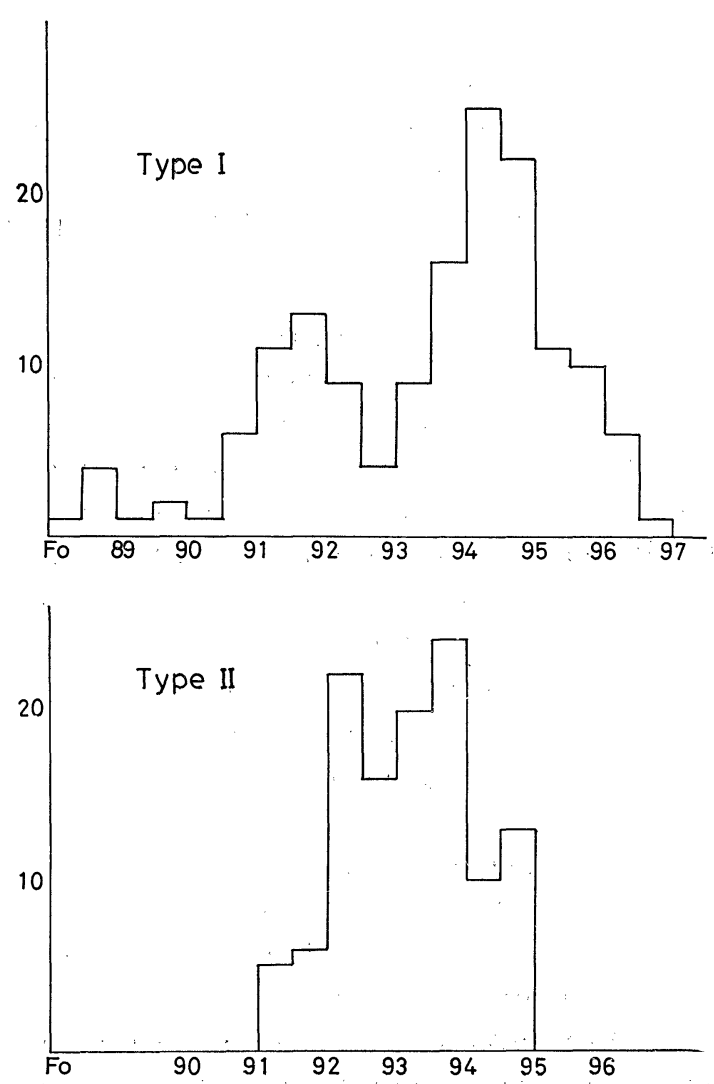

Fig. 3. Frequency histograms of Fo values of olivines in Type I and Type II of Tari-Misaka ultramafic rocks.' Ordinates: number of analyses.

$\mathrm{Mg} / \mathrm{Mg}+\mathrm{Fe}$ ) of olivine presents the bimodal character, that is, it can be classified into two groups, the Fe-rich group and the Mg-rich one (upper diagram of Fig. 3). The former tends to be free from opaque inclusions, while the latter often contains them (usually magnetite, sometimes sulfides).

In rocks of Type II, olivine often contains opaque inclusions, and the frequency histogram of Fo value (lower diagram of Fig. 3) is different from that of Type I. Orthopyroxene (enstatite) is characterized by extremely low content (almost nil) of CaO. Rocks of Type II sometimes contain tremolite, thus being, as a whole, more or less calciferous. Orthopyroxene in Type II is free from exsolution lamellae of clinopyroxene and sometimes enriched in opaque inclusions.

In rocks of Type III, olivine is free from opaque inclusions and Fo value is generally 91 or 92 . Thus, it is similar to that of the Ferich group in both chemical and textural features. Orthopyproxene 
sometimes possesses abundant exsolution lamellae of clinopyroxene and is free from opaque inclusions. It contains $1 \%$ to $2 \%$ of $\mathrm{CaO}$, as usual in orthopyroxene in Alpine-type peridotites of dunite-harzburgite series (e.g. Ross and others, ${ }^{6)}$ Challis, ${ }^{2)}$ Himmelberg and Coleman,4) Loney and others ${ }^{5)}$ ).

Cordierite, together with chlorite, olivine, and spinel, are found in one sample of Type IV.

\section{Petrogenic Interpretation}

Semi-concentric zonation of ultramafic rocks in Tari-Misaka complex appears to be controlled by granitic masses (Fig. 2). Type III periodotite, which is placed in the core of the complex, is similar to ordinary perioditites of dunite-harzburgite series both in texture and mineralogy. It may be interpreted not to have been affected by the thermal metamorphism of the granitic masses. Rocks of Types I and II have been more or less affected by it. The presence of cordierite in Type IV is an evidence of the thermal effect of the granitic masses upon the ultramafic complex. Cordierite may have been formed by dehydration of magnesian chlorite under low pressure (Fawcett and Yoder ${ }^{3)}$ ).

The modes of occurrence of rocks of Type I and II in the complex (Fig. 2), as well as their petrographic characters, are consistent with experimental results of Bowen and Tuttle. ${ }^{1)}$ According to them, under low pressure, serpentine is dehydrated into olivine and talc at about $500^{\circ} \mathrm{C}$, and into olivine and orthopyroxene at $600 \sim 700^{\circ} \mathrm{C}$. The former assemblage corresponds to talc-bearing dunite (i.e. Type I) and the latter, to harzburgite (i.e. Type II). Mineralogy of rocks of Types I and II may be well explained as due to the process : serpentinization of primary olivine $\rightarrow$ dehydration of serpentine to form secondary olivine. The pre-dehydration state is approximately represented by rocks of Type III. It is known that serpentine has generally higher $\mathrm{Mg} / \mathrm{Mg}+\mathrm{Fe}$ atomic ratio than olivine or orthopyroxene from which it has been derived. Fe must be balanced to fix in other phases such as magnetite or sulfides disseminated in serpentine. Thus, the dehydration products of serpentine, i.e. olivine and orthopyroxene, are expected to become more magnesian and to enclose minute grains of iron ores, provided that resorption of $\mathrm{Fe}$ is limited.

The bimodality in the histogram of olivines in rocks of Type I (Fig. 3) may be interpreted as indicating the difference of genesis between the two groups of olivines. The $\mathrm{Mg}$-rich olivines enriched in opaque inclusions were formed by dehydration of serpentine. On the other hand, the Fe-rich ones which are similar in composition to those in Type III are relics of the primary olivines in peridotite.

Mineralogical characters of rocks of Type II may be explained if 
complete serpentinite with or without clinnopyroxene relics is assumed as the pre-dehydration state. Textural similarity of olivine in Type II with that of Mg-rich group in Type I indicates the same process of formation. The former may have been more Fe-enriched because of stronger partial resorption of $\mathrm{Fe}$ on dehydration.

In rocks of Type I or Type II, initial clinopyroxene, if present, was transformed into tremolite at low temperature before commencement of dehydration. Tremolite may be stable even at the temperature of formation of orthopyroxene by dehydration of serpentine. The elimination of $\mathrm{Ca}$ from the reaction system of dehydration was performed by this process and orthopyroxene extremely depleted in $\mathrm{Ca}$ was formed.

Dunite-harzburgite complexes are ubiquitous in orogenic belts. Serpentinization-dehydration process as discussed in this paper might possibly have taken place also in the formation of some of those complexes.

\section{Acknowledgement}

The writer wishes to express his hearty thanks to Emeritous Professor S. Tsuboi for reviewing this paper in manuscript and communicating it to the Academy. He is grateful to Professors T. Fujii and S. Aramaki of University of Tokyo, under whose guidance this work has been done.

\section{References}

1) N. L. Bowen and O. F. Tuttle (1949): Bull. Geol. Soc. Am., 60, 439-460.

2) G. A. Challis (1965): J. Petrol., 6, 322-364.

3) J. J. Fawcett and H. S. Yoder, J. (1966) : Am. Mineral., 51, 353-380.

4) G. A. Himmelberg and R. G. Coleman (1968) : U. S. G. S. Prof. Paper 600-C, 18-26.

5) R. A. Loney, G. A. Himmelberg, and R. G. Coleman (1971): J. Petrol., 12, 245-309.

6) C. S. Ross, M. D. Foster, and A. T. Myers (1954) : Am. Mineral., 39, 693-737. 